The Korean Journal of Parasitology

Vol. 34, No. 1, 15-20, March 1996

\title{
Differentiation of Korean isolates of Entamoeba histolytica from Entamoeba dispar
}

\author{
Seong-Choon $\mathrm{CHOE}^{\prime \prime}$, Mejeong Lee ${ }^{1)}$, Sang-Kum LEE ${ }^{2)}$, Kyung-il IM ${ }^{3)}$, \\ Egbert TANNICH ${ }^{41}$, Soon-Hyung $\mathrm{LEE}^{11}$, and Sung-Tae HONG ${ }^{1 * *}$
}

\begin{abstract}
Department of Parasitology and Institute of Endemic Diseases ${ }^{1)}$, Seoul National University College of Medicine, Seoul, 110-799, Department of Clinical Pathology 2), Seoul Paik Hospital Seoul 100-031, Department of Parasitology33, Yonsei University College of Medicine Seoul 120-752, Korea, Bernhard Nocht Institute for Tropical Medicine4), 20359 Hamburg. Germany
\end{abstract}

\begin{abstract}
Cysts of Entamoeba histolytica are still found from humans in Korea, but not all of the cysts are known as pathogenic. The non-pathogenic strain is regarded as a different species, E. dispar. In this study, Korean isolates of conventional E. histolytica were subjected for the differentiation by polymerase chain reaction (PCR) and restriction fragment length polymorphism (RFLP) analysis. Human stools were screened by routine microscopic examination, and cyst or trophozoite positive stools were inoculated into Robinson media. The cultivated trophozoites were prepared for DNA extraction, and the DNAs were used for PCR with common primers of P1 gene. The PCR products were digested with 3 restriction enzymes and RFLP was observed. Also anti-sense primers containing the cleavage site of each restriction enzyme were designed for differentiation only by PCR. The PCR products of Korean isolates S9, S12, YS-6, and YS-27 were spliced by Taq I and Xmn I but not by Acc I, and the isolates S1, S3, S11, S15, S16, S17, S20, YS17, and YS-44 were spliced by Acc I but not by Taq I and Xmn I. These RFLP pattern correlated well with PCR products by the species specific primers. The findings confirm that the Korean isolates S9, S12, YS-6, and YS-27 are E. histolytica and others are E. dispar. In Korea, most of the asymptomatic cyst carriers are infected by $E$. dispar, not by E. histolytica
\end{abstract}

Key words: Entamoeba histolytica, Entamoeba dispar, Korean isolates, polymerase chain reaction (PCR), restriction fragment length polymorphism (RFLP)

\section{INTRODUCTION}

Entamoeba histolytica Schaudinn, 1903 is a pathogenic amoeba which grows primarily in the intestine of human. There had been evidences that pathogenic and non-pathogenic strains are present in E. histolytica (Mirelman, 1987; Edman et al, 1990; Blanc, 1992). The two strains were proved different in genetic

- Received Jan. 15 1996, accepted Feb. 11996.

* Corresponding author structures (Tannich et al., 1989; Tannich and Burchard, 1991: Abd-Alla et al., 1993), and it is finally concluded that pathogenic and nonpathogenic strains are different species which have evolved for several million years. Therefore, the nomenclature was rearranged as that the pathogenic amoeba is Ertamoeba histolytica and non-pathogenic amoeba is Entamoeba dispar Brumpt, 1925 (Diamond and Clark, 1993). However clear-cut differentiation of them still remains problematic because the two species are same 
in their morphologic characteristics, and thus differentiation is tricky.

The amoebas are differentiated through various molecular biologic methods including the analysis of the amplified P1 gene by PCR and RFLP (Tannich and Burchard 1991), zymodeme analysis (Blanc, 1992), antigen specificity (Gonzalez-Ruiz et al., 1992; Lotter et al., 1992), and determination of the specific coproantigen (Haque et al, 1993; GonzalezRuiz et al., 1994).

Infection of $E$. histolytica has taken a high toll in the population all across the world and it is estimated that more than 50 million people throughout the world are infected with E. histolytica. It is assumed that $10 \%$ out of the infected people develop clinical enteritis or extraintestinal abscess. In the United States, the number of clinical patients with amebiasis runs up to 70,000 annually. A recent paper recorded the cyst positive rate of $E$. histolytica was alarming as $0.9 \%$ in U.S.A. (Kappus et al. 1994). However, the overall prevalence of $E$. histolytica infection may be overestimated due to same morphology of $E$. histolytica and $E$. dispar. Most of the reports have mixed the two.

Strictly speaking, the same situation is true in Korea. Prevalence of E. histolytica in Korea has been overestimated definitely since the rate usually included $E$. histolytica, E. dispar and E. hartmanni altogether. Based on the report by Kessel (1925), the first report in Korea on prevalence of amoeba cysts, $41 \%$ out of the total 208 examinees passed cysts of $E$. histolytica. Since then, the cyst positive rates maintained $5 \sim 10 \%$ until early 1970 's and Lee (1973) showed a cyst positive rate of $7.7 \%$ out of 4,447 examinees. Afterwards, according to rapid industrialization throughout the country, improvement in water-supply facilities. decreases in the use of human manure and fertilizer, and amelioration in individual hygiene, the positive rate of cysts fell off below $1 \%$ in the late 1970 's and decreased to $0.5 \%$ in the late 1980's and 1990's (Hong, 1994). But differentiation of the three Entamoeba species has never been tried in Korea.

At present the differentiation of pathogenic E. histolytica from non-pathogenic $E$. dispar is desperately needed in Korea. The objective of this study was to differentiate $E$. histolytica from E. dispar, isolated from humans in Korea, through DNA analysis of Pl gene by PCR and RFLP.

\section{MATERIALS AND METHODS}

\section{Amoebas}

The isolates of amoebas used in the experiment were 13 altogether. These were $\$ 1$, S3, S9, S11, S12, S15, S16, S17, S20, YS-6, YS-17, YS-27, and YS-44, isolated from 13 patients or cyst carriers in Korea. These specimens were collected at the Seoul National University Hospital, Seoul Paik Hospital, and Yonsei Medical Center. The strain of HM-1: IMSS was the standard of $E$. histolytica. The human stools which were cyst positive by formalin-ether concentration technique were cultivated in Robinson medium, and the subcultivated trophozoites in Robinson medium or TY5GM-9 were used for this analysis. The axenized isolates, YS-27 (Chang et al, 1995) and HM-1:IMSS, were maintained in the medium TYI-S-33.

\section{Preparation of DNA}

The cultivated trophozoites were washed in cold saline and resuspended in $400 \mu \mathrm{l}$ of water. The bursted trophozoites were successively treated with phenol, chloropane and chloroform. The supernatant was stored frozen and used as template DNA for PCR.

\section{Polymerase chain reaction (PCR)}

The oligonucleotides of PI gene synthetised in the Korea Biotech Co. were used as primers. The sense primer was Pl-\$17 (5'-GCAACTAGTGTTAGTTA-3'), and the common antisense primer was P1-AS20 (5'-CCTCCAAGATATGTTTTAAC-3') for both species (Tannich and Burchard, 1991). The species specific antisense primers were pathogenic P1-AS16 including $X m n$ I restriction site (5'AAGCCCTTCCTGTATC-3') for E. histolytica and nonpathogenic NP1-AS16 including ACC I restriction site (5'-TAGACGTACCAGTATA-3') for E. dispar.

The reaction mixture for PCR was $50 \mu \mathrm{l}$ which was composed of the primers 100 pmole, dNTP mix $10 \mathrm{mM}$ each, tDNA 50 100 $\mu \mathrm{g}$, and Taq DNA polymerase 2.5 unit. After 
keeping for five minutes at $94^{\circ} \mathrm{C}, 3$ step thermocycling was repeated 35 times; 30 seconds at $94^{\circ} \mathrm{C}$ for denaturation, 30 seconds at $57^{\circ} \mathrm{C}$ for annealing, and 45 seconds at $72^{\circ} \mathrm{C}$ for extension. After completion of the cycles, the reaction was held for 10 minutes at $72^{\circ} \mathrm{C}$. The PCR products were electrophoresed in $1 \%$ agarose mini-gel containing ethidium bromide. and visualized through UV illumination. The photopicture was taken with a polaroid camera. The PCR product was precipitated by mixing with ethanol and sodium acetate salt. The DNA precipitate was spun down and dried, and resuspended in 30-50 $\mu 1$ water.

\section{Restriction fragment length polymorphism (RFLP)}

The redissolved PCR products were aliquated into $8 \mu \mathrm{l}$, and $10 \times$ buffer solution $1 \mu \mathrm{l}$ and 1 $\mu 1$ of each endonuclease were added. The enzymes reacted for 2 hours at $37^{\circ} \mathrm{C}$ for $X m n$ I and $A c c \mathrm{I}$, and at $65^{\circ} \mathrm{C}$ for $\mathrm{Taq} \mathrm{I}$. The results were observed through running on $1.5 \%$ agarose gels as mentioned above.

\section{RESULTS}

The DNA bands shown in Fig. 1 are the 482 bp product extended with the common primers and 292 bp product with species specific primers. The $482 \mathrm{bp}$ product was digested by restriction enzymes, Taq I, Xmn I, and Acc I as presented in Fig. 2. The PCR products of 4 Korean isolates; $\$ 9, \mathrm{S12}$, YS-6, and YS-27, were cut by Taq I and Xmn I into 2 bands but not by Acc I. They also made PCR product with the primer pairs of Xmn I sequence, Pl-AS16 (Fig. 1). Therefore these four isolates are $E$. histolytica. The PCR products with common primers of the isolates, S1, S3, S11, S15, S16, S17, S20, YS-17, and YS-44, were cut by Acc I but not by Taq I and $X_{m n}$ I. Of course they showed PCR products with the primers of the Acc I sequence, NP1-AS16 (Fig, 1). The 9 isolates are confirmed as $E$. dispar. The present findings and clinical records are summarized in Table 1.

\section{DIScUSsIoNs}

The present findings confirm that most of

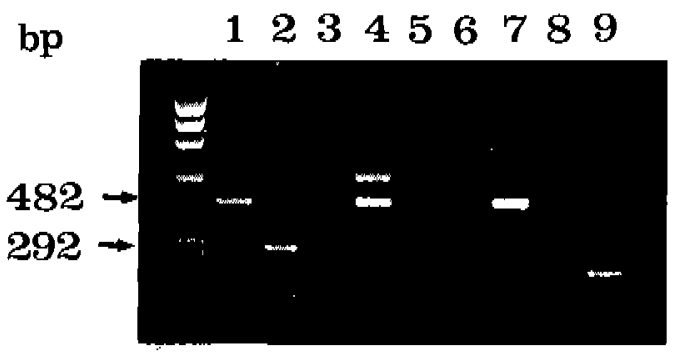

Fig. 1. PCR products of HM-l \& 512 (E. histoly(ica) and $\$ 15$ (E. dispar) with the primer pairs of $\mathrm{P} 1-\mathrm{S} 17$ and 3 antisense primers. 1-3. HM-1 amoeba lemplate DNA with primers of comnon P1-AS20, pathogenic P1-AS16, and nonpothogenic NP1-AS16; 4-6, S12 amoeba template DNA with primers of common Pl-AS20, pathogenic Pl-AS16, and non-pathogenic NP1AS16; 7-9, S15 amoeba template DNA with primers of common P1-AS20, pathogenic PlAS16, and non-pathogenic P1-NAS16.

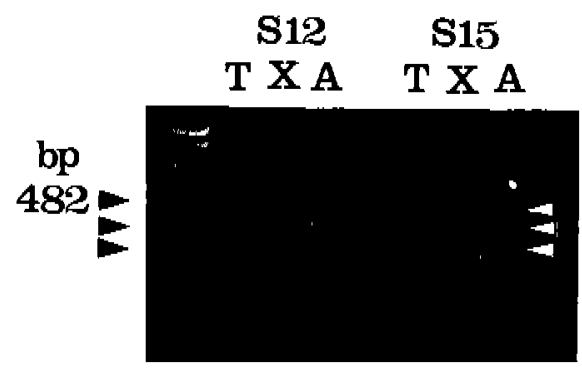

Fig. 2. Restriction patterns of 482 bp PCR products of $S 12$ (E. histolytica) and $S 15(E$. dispar) template DNAs with common primers of P1-S17 and P1-AS20, S12 product was digested into two fragments; 321 and 161 bp by $T$, and 291 and 191 bp by X. S15 product was digested into two fragments, 292 and 190 bp by A. Restriction enzymes: T. Taq I; X, Xmn I; A, Acc I.

the asymptomatic cyst passers of $E$. histolytica in Korea are not infected by $E$. histolytica but infected by $E$. dispar. Out of 13 Korean isolates, S9, S12, YS-6 and YS-27 were proved as $E$. histolytica. The $\mathbf{S 9}$ was isolated from a 10-year old girl who suffered from bloody diarrhea at Inchon in 1994 and $\$ 12$ was isolated in 1994 from a Korean man who had been to Indonesia where diarrheal colitis appeared first. YS-6 and YS-27 were isolated in 1960 s at Yonsei Medical Center from patients of colitis and liver abscess respectively. YS-27 is an axenized isolate (Chang et al, 1995). 
Table 1. Differentiation of E. histolytica and E. dispar among 13 Korean Entamoeba isolates

\begin{tabular}{|c|c|c|c|c|c|c|c|c|}
\hline \multirow{2}{*}{$\begin{array}{l}\text { Isolates } \\
\text { (year) }\end{array}$} & \multicolumn{3}{|c|}{ PCR with primers } & \multicolumn{3}{|c|}{ Restriction of $482 \mathrm{bp}$} & \multirow{2}{*}{$\begin{array}{l}\text { Symptoms } \\
\text { (travel history) }\end{array}$} & \multirow{2}{*}{ Species } \\
\hline & AS20 & AS16 & NAS16 & $\operatorname{Taq} \mathrm{I}$ & $X m n I$ & $\operatorname{Acc} \mathrm{I}$ & & \\
\hline S1 (1993) & 0 & - & 0 & - & - & 0 & diarrhea & E. dispar \\
\hline S3 (1993) & 0 & - & 0 & - & - & 0 & symptomless & E. dispar \\
\hline$\$ 9$ (1994) & 0 & 0 & - & 0 & 0 & - & diarrhea & E. histolytica \\
\hline S1 1 (1994) & 0 & - & 0 & - & - & 0 & symptomless & E. dispar \\
\hline S12 (1994) & 0 & 0 & - & 0 & 0 & - & diarrhea (Indonesia) & E. histolytica \\
\hline S15 (1994) & 0 & - & 0 & - & - & 0 & symptomless & E. dispar \\
\hline S16 (1994) & 0 & - & 0 & - & - & 0 & symptomless & E. dispar \\
\hline$\$ 17(1994)$ & 0 & - & 0 & - & - & 0 & symptomless & E. dispar \\
\hline \$20 (1995) & 0 & - & 0 & - & - & 0 & symptomless & E. dispar \\
\hline YS-6 (1960s) & 0 & 0 & - & 0 & 0 & - & diarrhea & E. histolytica \\
\hline YS-17 (1960s) & 0 & - & 0 & - & - & 0 & symptomless & E. dispar \\
\hline YS-27 (1969) & 0 & 0 & - & 0 & 0 & - & liver abscess & E. histolytica \\
\hline YS-44 (1970s) & 0 & - & 0 & - & - & 0 & symptomless & E. dispar \\
\hline HM-1:IMSS & 0 & 0 & - & 0 & 0 & - & & E. histolytica \\
\hline
\end{tabular}

S1, S3, \$11, \$15, \$16, \$17, YS-17, and YS44 were found as $E$. dispar. The $\$ 1$ was isolated from a patient of diarrhea but others were from cases who were found cyst positive by routine stool examination without any related symptoms of amoebiasis. All of the symptomless carriers and one (S1) of the 4 diarrheal patients ( $\mathrm{S} 1, \mathrm{~S} 9, \mathrm{~S} 12$, and YS-6) were proved to be infected by the non-pathogenic Entamoeba. Since the amoeba, E. dispar, is not invading the intestinal mucosa, the carrier of S1 isolate had diarrhea which must have been caused by other undetermined reasons.

Cysts of Entamoeba species recovered in human stools are classified into 3 species by microscopic morphology, E. coli. E. hartmanni, and $E$. histolytica (including $E$. dispar). E. coli cyst is larger than $10 \mu \mathrm{m}$ and has $1 \sim 8$ nuclei. The cyst of $E$. hartmanin is smaller than $10 \mu \mathrm{m}$ in diameter. The cyst sized $10 \sim 20 \mu \mathrm{m}$ with $1 \sim 4$ nuclei is $E$. histolytica or $E$. dispar. However, $E$. dispar cyst is indistinguishable from that of $E$. histolytica on the basis of morphological traits. Furthermore, some papers reported that one isolate of non-pathogenic $E$. histolytica was changed into pathogenic one during long-term cultivation (Mirelman et al., 1986a \& b). Some groups asserted that the pathogenic and nonpathogenic characteristics were changeable. After confusing debates, it is now accepted that the confusing reports were the outcome of contamination during cultivation (Clark and Diamond, 1993).
Differentiation of $E$. histolytica from $E$. dispar is practically crucial for definite diagnosis and proper management of the patients. Although the cyst-passers have symptoms of colitis. further study should find out the real etiology if the cysts are confirmed as $E$. dispar. The cyst-passers of E. dispar, E. hartmanni and $E$. coli should not be essentially treated by antiamoebic medication.

In Korea, cyst-passers of E. dispar are much more than those of E. histolytica. Only less than one quarter of the cyst positives are the real targets of medical cares for amebiasis. This is the common feature throughout the world except for hyperendemic areas (Tannich and Burchard, 1991).

Development of an easier and handier method to differentiate $E$. histolytica from $E$. dispar is essential because PCR and RFLP analysis used in the present study is rather complicated, tricky, and costful. Furthermore it takes several days for cultivation. Therefore, simplification of PCR and RFLP remains necessary. Diagnosis by PCR only is much easier than PCR and RFLP as revealed through the present study. The antisense primers which include the sequences of Xmn I and $A c c$ I restriction sites produce different amplification between the two species. The primer pair with sequences of Xmn I site amplifies the DNA fragment of only $E$. histolytica while the primer with sequences of Acc I site amplifies the DNA of only $E$. dispar. 
These primer pairs can differentiate the two species by PCR only.

To adopt the PCR technique in mass screening, direct extraction of amoeba DNA from feces without cultivation is more effective than DNA extraction from cultivated amoebas. The method described by KatzwinkelWladarsch et al. (1994) requires no cultivation of amoebas and provides more sensitive and selective differentiation. This method is simple because all extraction steps can be performed at room temperature and there are no steps of precipitation and hybridization. The whole procedure can be performed in one day. We should screen reproducibility and accuracy of the method.

Immunodiagnosis by screening the coproantigen which reacts with the monoclonal antibody is the best candidate at present for differentiating these amoebas (Haque et al, 1993; Gonzalez-Ruiz et al., 1994). It must be compared that which one is more feasible in definite diagnosis between the rapid one step PCR and the coproantigen screening.

In conclusion, the present study proves that non-pathogenic $E$. dispar is more prevalent than $E$. histolytica in Korea. All of asymptomatic cyst carriers and even one patient with diarrhea were infected by $E$. dispar. PCR only with selective primers of $\mathrm{Pl}$ gene can be successfully applied to differentiate E. histolytica from E. dispar.

\section{ACKNOWLEDGEMENT}

The authors would highly appreciate technical assistance of Mr. Jae-Lip Kim in Department of Parasitology and Institute of Endemic Diseases, Seoul National University College of Medicine.

\section{REFERENCES}

Abd-Alla MD, Jackson TFHG, Gathiram V, E1Hawey AM, Ravdin JI (1993) Differentiation of pathogenic Entamoeba histolytica infections from nonpathogenic infections by detection of galactose-inhibitable adherence protein antigen in sera and feces. $J$ Clin Microbiol 31 (11): $2845-2850$.

Blanc DS (1992) Determination of taxonomic status of pathogenic and nonpathogenic
Entamoeba histolytica zymodemes using isoenzyme analysis. $J$ Protozool 39(4): 471479.

Chang JK, Im K, Soh CT (1995) Axenization of Entamoeba histolytica, a Korean strain YS-27. Korean J Parasitol 33(4): 387-390.

Clark CG, Diamond LS (1993) Entamoeba histolytica: An explanation for the reported conversion of "non-pathogenic" amebae to the "pathogenic" form. Exp Parasitol 77: 456-460.

Diamond LS, Clark CG (1993) A redescription of Entamoeba histolytica Schaudinn, 1903 (emended Walker, 1991) separating it from Entamoeba dispar Brumpt. 1925. J Euk Microbiol 40: 340-344.

Edman U, Meraz MA, Rausser S, Agabian N, Meza I (1990) Characterization of an immunodominant variable surface antigen from pathogenic and nonpathogenic Entamoeba histolytica. J Exp Med 172(3): 879-888.

Gonzalez-Ruiz A, Haque $\mathrm{R}$, Rehman $\mathrm{T}$, et al. (1992) A monoclonal antibody for distinction of invasive and noninvasive clinical isolates of Entamoeba histolytica. J Clin Microbiol 30(1 1): 2807-2813.

Gonzalez-Ruiz A, Haque R, Rehman T, et al. (1994) Diagnosis of amebic dysentery by detection of Entamoeba histolytica recal antigen by an invasive strain-specific, monoclonal antibody-based enzyme-linked immunosorbent assay. J Clin Microbiol 32(4): 964-970.

Haque R, Kress K, Wood S, et al. (1993) Diagnosis of pathogenic Entamoeba histolytica infection using stool ELISA based on monoclonal antibodies to the galactose-specific adhesin. $J$ Infect Dis 167: 2476-2479,

Hong ST (1994) Intestinal protozoan infections among people in Korea. Collected Papers on Parasite Control in Korea. The Korea Association of Health, Seoul.

Kappus $\mathrm{KD}$, Lundgren RG Jr, Juranek DD, Roberts JM, Spencer HC (1994) Intestinal parasitism in the United States: Update on a continuing problem. Am $J$ Trop Med Hyg $\mathbf{5 0}$ (6): 705-713.

Katzwinkel-Wladarsch S, Loscher T, Rinder H (1994) Direct amplification and differentiation of pathogenic and nonpathogenic Entamoeba histolytica DNA from stool specimens. Am $J$ Trop Med Hyg 51(1): 1 15-118.

Kessel JF (1925) A preliminary report on the incidence of human intestinal protozoan infections in Seoul, Korea. China Med $J$ 
XXXIX, 11 .

Lee SH (1973) Study on the status of intestinal protozoan infections in Koreans. J Health Fell Found 3: 1-6.

Lotter H, Mannweiler E, Schreiber M. Tannich E (1992) Sensitive and specific serodiagnosis of invasive amebiasis by using a recombinant surface protein of pathogenic Entamoeba histolytica. J Clin Microbiol 30(12): 31633167.

Mirelman D (1987) Effect of culture conditions and bacterial associates on the zymodemes of Entamoeba histolytica. Parasitol Today 3(2): 37-40.

Mirelman D, Bracha R, Chayen A, Aust-Kettis A, Diamond LS (1986a) Entamoeba histolytica: Effect of growth conditions and bacterial associates on isoenzyme patterns and virulence. Exp Parasitol 62: 142-148.

Mirelman D, Bracha R, Wexler A, Chayen A (1986b) Changes in isoenzyme patterns of a cloned culture of nonpathogenic Entamoeba histolytica during axenization. Infect Immun 54: 827-832.

Tannich E, Buchard GD (1991) Differentiation of pathogenic from nonpathogenic Entamoeba histolytica by restriction fragment analysis of a single gene amplified in vitro. $J$ Clin Microbiol 29(2): 250-255.

Tannich E, Horstmann RD, Knobloch, Arnold HH (1989) Genomic DNA differences between pathogenic and nonpathogenic Entamoeba histolytica. Proc Natl Acad Sci USA 86: 51185122 .

\title{
우리 나라에서 분리한 이질아메바(Entamoeba histolytica)와 동형아메바(Entamoeba dispar)의 감별
}

\author{
최성준1), 이미정 1), 이상금2), 임경일3), Egbert Tannich4), 이순형 ${ }^{13}$, 홍성태1) \\ 서울대학교 의 과대학 기생훙학고실 및 풍토병연구소11, 인제대학교 의과대학 부속 서울뱁병원 임상병리과2),

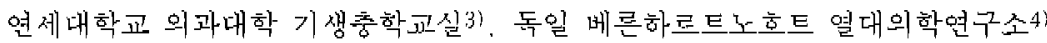

이질아메바(Entamoeba histolytica) 와 동형아메바(Entamoeba dispar. 同形아네바)의 포낭 은 형태학적으로 구분이 안되어 종 감별에 관하여 논란이 있어 왔다. 최근에 이 둘이 별쫑이 며 톡히 이질아메바는 병원성이고. 동형아메바는 비병횐성입이 확인되어 그 감별이 중효한 의 미를 갖게 되었다. 이 연구에서는 우리 나라의 아메바 분리체 를 중합효소 반응과 제한효소 반 응을 이용하여 도 종으로 감별하였다. 1994-1995년에 대변을 동상의 방법으로 겸색하여 포 낭이나 영얌혐이 발견된 검체를 로빈슨 배지에서 배양하고 배양된 영양혐에서 DNA볼 분러하 였다. P1 유전자 엄기서열 중에저 시발체 (primer) 를 만들어 중합호소 반응으로 $482 \mathrm{bp}$ 크기 의 산물을 얻고 이를 제한효소(Taq I, XImn I. $A c c$ I)로. 처리하였다. 또한 Xnn I과 Acc I 체한 효소의 톡이 염기서열을 포함하는 시발체를 제작하여 따로 중합효소 반응을 시행하였다. 그 결과 13 개 분러체 중에서 S9, S12. YS-6. YS-27의 $482 \mathrm{bp}$ 산물은 Taq I과 Xmn I에 의하 여. 그 외의 분러체 산물온 $A c c$ I에 외하여 절단되었다. 이 결과는 특이 염기서열 시발체의 중합호소 반웅에서 얻은 산물과 일치하였다. 이 결과이 의하여 분리쳬 S9, S12, YS-6는 대 장염 환자에서. YS 27 은 간농양 환자에서 분리한 병원성의 이질아메바(E. histolytica)이고. 분러체 S1, S3, S11, \$15, S16, S17, S20, YS-17, YS-44는 무증상의 포낭배훌자에서 얻 은 비병원섬의 동형아메바-(E. dispar)로 구별할 수 있었다. S1은 설사 환자에서 얻은 분리체 이지만 동형아메바임을 확인하였고. 따라서 이 환자의 설사는 다른 원인에 의한 것으로 환단 된다. 이로서 비병뭔성인 동형아메바가 우리 나라에서도 병원성 이질아메바보다 더 흔하게 존 재한다는 것을 처음으로 기록하며 E. dispar의 우러 말 이름을 동형아메바로 제안한다.

(기생춯학잡지, 33(4): 15-20, 1996년 3월] 